\title{
STRUCTURE, COMPOSITION AND DISTRIBUTION \\ OF BENTHIC MACROINVERTEBRATES IN \\ EL-SALAM CANAL, EGYPT
}

\author{
Mohamed R. A. Fishar
}

National Institute of Oceanography and Fisheries, Inland Water and Aquaculture Branch, 101 Kasr El-Aini Street, Cairo, Egypt

Key words: Macrobenthic invertebrates, distribution, composition, El-Salam Canal.

\begin{abstract}
Q uantitative estimation of macro-bottom fauna in El-Salam Canal was carried out seasonaly from autumn 1999 to summer 2000 . The macrobenthic community consists of Arthropoda, Annelida and Mollusca. Diversity of benthic fauna in the canal was low due to the shortly constructed water body and its newly established community. Besides, the average biomass in the canal was much higher than that previously recorded in different parts of River Nile. This is attributed to the heavy weight and big size of some molluscan species recorded at the end stations of the canal. Temperature and dissolved oxygen were the most important parameters controlling the distribution of macrobenthic invertebrates in the canal.
\end{abstract}

\section{INTRODUCTION}

Information on the structure and functioning of newly constructed canals is necessary for the proper management and conservation of the freshwater resources in these ecosystems. It is also necessary for drawing up monitoring programes of these ecosystems to preserve and conserve their biodiversity (Tumwesigye et al., 2000). A detailed knowledge on the composition, distribution and abundance of bottom fauna in newly established canals, both in time and space, is thus a pre-requissite for the scientific management of these canals since this community plays an important role in aquatic ecosystems. The importance of the present study results from being the first to deal with the ecology of macrobenthic invertebrates in this newly constructed irrigation canal (El-Salam Canal). 


\section{MATERIALS AND METHODS}

\section{study area}

Horizontal agricultural expansion in Sinai requires providing it with irrigation water from the Nile in addition to other water sources such as rain and subterranean water. Hence, the Government of Egypt is embarking on the reuse of drainage water from El Salam Canal to irrigate approximately 620,000 feddans of new lands in the northeastern Delta and northem Sinai Peninsula (Serag and Kheder, 1996). Overall integrated development of Sinai necessitates linking the east side of the Suez Canal and Sinai with the western side, since these two sides are organically united and constitute one comprehensive strategic area.

The Canal takes its supply of water from the right side of Damietta tributary at $\mathrm{km} 219$. The canal extends $87 \mathrm{~km}$ from the Nile till west Ismailia/Port Said highway, passing through Damietta, Daqahleya, Sharqueya and Port Said governorates. The Canal takes the south eastern side passing near Al-Attawe drainage to the site of Al-Serw where it is possible to benefit from 2 million cubic meters of waters daily and can be mixed with the waters of Al-Salam, at $\mathrm{km} 20$. At $\mathrm{km} 39$ the Canal intersects with Al-Taweel Bahari drainage, where it goes westwards until it crosses Hadous drain at $\mathrm{km} 53$, where two stations for pumping and mixing were established. It is then diverted to cross Bahr El-Baqar drain at $\mathrm{Km} 77$ to the east until it meets the Suez Canal at $\mathrm{km}$ 86. Al-Salam Canal, as the phase located in Sinai, will be named after Sheikh Gaber Al-Sabah and is $155 \mathrm{~km}$ long and will irrigate 400,000 feddans east of Suez Canal.

Sampling of macroinvertebrates and some water quality analysis were surveyed seasonly from autumn and winter of 1999 to summer of 2000. Samples were taken from five selected sites. The sampling sites and their distance from mouth of the canal are described in the following:

Station I: At the mouth of the canal at Farskour

Station II: At $\mathrm{Km} 20$ beside the mixing point with agricultural drainage water of El-Serw Drain.

Station III: at $\mathrm{Km} 43$ at the entrance of El-Mataryia Town.

Station IV: At $\mathrm{Km} 53$ beside the stations of pumping and mixing water of Hadous Drain. Station V : at Km 63.

Some physicochemical parameters such as air and water temperature and $\mathrm{pH}$ were measured by using a digital $\mathrm{pH}$ meter model 370 Jenway. Transparency was determined by using a secchi 
disc.The other chemical parameters were studied in detail by Sabae and Abdel-Satar (2001).

The benthic samples were collected from the sampling localities using Ekman Grab with opening area equivalent to $250 \mathrm{~cm}^{2}$. The collected samples were washed in the field through a small hand net of $500 \mu \mathrm{m}$ mesh diameter. The samples were stored in plastic jars after adding $7 \%$ formalin solution. Sorting and identification of different species were carried out in the laboratory. Results were given as the total number of individuals per square meter, while their biomass in gram fresh weights per square meter (G. F. W. $/ \mathrm{m}^{2}$ ).

\section{RESULTS}

\section{1-Physico - chemical Parameters}

As shown in Table (1), the maximum air and water temperature were recorded in summer $\left(37^{\circ} \mathrm{C}\right.$ and $28^{\circ} \mathrm{C}$ for air and water respectively), while the minimum values were observed during winter $\left(19.3^{\circ} \mathrm{C}\right.$ for air and $19^{\circ} \mathrm{C}$ for water $)$.

The transparency values fluctatited between $20 \mathrm{~cm}$ during summer to $105 \mathrm{~cm}$ during winter: Concerning variation in sites, there was a gradual desrease from station I to station $\mathrm{V}$.

The depth of the canal varied from $150 \mathrm{~cm}$ to $400 \mathrm{~cm}$, depending on the water level in the canal which is controlled by the Nile and drainage water discharged into it from feeding drains.

The $\mathrm{pH}$ values of water varied from 6.83 at station I during spring to 7.42 at station II during summer.

\section{2-Community composition:}

During the present investigation, the macrobenthic invertebrates in the investigated area were represented by three phyla namely, Annelida, Arthropoda and Mollusca. The latter was the most dominant benthic group constituting $47.98 \%$ and $99.53 \%$ of the total benthic number and weight respectively. It was followed by Annelida which constituted $31.21 \%$ of the total number and $0.35 \%$ of the total weight and Arthropoda with $20.81 \%$ and $0.12 \%$ of the total population density and biomass respectively (Fig. 1). 


\section{3- Spatial and seasonal distribution among stations:}

The spatial distribution of population density and biomass of total macroinvertbrates in sampling localities showed that stations IV \& V were the richest sites in th canal, where 4840 organisms $/ \mathrm{m}^{2}$ weighing 1282 G. F. W. $/ \mathrm{m}^{2}$ and 3880 organisms $/ \mathrm{m}^{2} 859.09$ G. F. W. $/ \mathrm{m}^{2}$ were captured respectivly. In other sampling sites, the population density and biomass fluctuated between 1360 organisms $/ \mathrm{m}^{2}, 216.72 \mathrm{G} . \mathrm{F} . \mathrm{W} . \mathrm{m}^{2}$ in satation II and 2200 organisms $/ \mathrm{m}^{2}$ weighing, 286.14 G.F. $\mathrm{W} . / \mathrm{m}^{2}$ in station I (Fig. 2).

Regarding temporal distribution of macroinvertebrates, spring was the most productive season, with a value of 1152 organisms $/ \mathrm{m}^{2}$. A remarkable decrease was recorded during the next seasons. At the sametime, the minimum value was observed during summer. A seasonal biomass variation followed the same trend of population density (Fig.3).

\section{4- Spatial and seasonal distribution among the three phyla: a-Mollusca:}

Mollusca occupied the first position in macrobenthic invertebrates. It was represented by 8 species of which 6 gastropods namely: Melanoides tuberculata, Gyralus ehrenbergi, Bellamya unicolor, Lanstes carinatus, Physa acuta and Cleopatra bulimoides and 2 bivalves namely: Corbicula consbrina and Mutela aubia nilotica were reported. The annual average value of population density of the above species ranged between 3650 organisms $/ \mathrm{m}^{2}$ recorded at station IV and 320 organisms $/ \mathrm{m}^{2}$ at stations I \& II. The average biomass that ranged from $1279.2 \mathrm{G}$. F. W. $/ \mathrm{m}^{2}$ was recorded in station IV to $212.12 \mathrm{G}$. F. W. $/ \mathrm{m}^{2}$ in satation II. The highest population density and biomass in sampled localities (1760 organisms $/ \mathrm{m}^{2}$ weighing $376.96 \mathrm{G} . \mathrm{F} . \mathrm{W} . / \mathrm{m}^{2}$ ) were recorded at station IV during winter, while the organisms of this phylum disappeared completely from stations I \& II during summer (Fig.4).

\section{b-Annelida:}

Phylum Annelida was represented by three species belonging to two classes; Tubificidae and Hirudinea. The annual average value of population density of annelids ranged between 1760 organisms $/ \mathrm{m}^{2}$ recorded at station I and 200 organisms $/ \mathrm{m}^{2}$ at station V. The average 
biomass ranged from $4.922 \mathrm{G} . \mathrm{F} . \mathrm{W} . \mathrm{m}^{2}$ at satation I to $0.352 \mathrm{G} . \mathrm{F}$. $\mathrm{W} . / \mathrm{m}^{2}$ at satation III. The highest population density and biomass (720 organisms $/ \mathrm{m}^{2}$, weighing $3.946 \mathrm{G}$. F. W. $/ \mathrm{m}^{2}$ ) were recorded at station I during spring, while the organisms of this phylum disappeared completely from stations III,IV\& Vduring winter (Fig.5).

\section{c-Arthropoda:}

Arthropoda occupied the third position in distribution after Mollusca and Annelida. Only three species belonging to each of Ostracoda (Cyprides torosa), Insecta (larvae and pupae of Chironomidae) and Amphipoda (Corophium sp.) were recorded in the investigated area. The annual average value of population density of Arthropoda varied from 2200 organisms $/ \mathrm{m}^{2}$ at station $\mathrm{V}$ and 80 organisms $/ \mathrm{m}^{2}$ at station III, while the average biomass ranged from $2.768 \mathrm{G}$. F. W. $/ \mathrm{m}^{2}$ at satation I to $0.044 \mathrm{G}$. F. W. $/ \mathrm{m}^{2}$, at satation III. The highest population density and biomass $\left(1920\right.$ organisms $/ \mathrm{m}^{2}$ weighing 2.745 G. F. W. $/ \mathrm{m}^{2}$ ) was recorded at station V during spring, while the organisms of this phylum disappeared completely from many stations especially during winter and spring (Fig.6).

\section{DISCUSSION}

The macrobottom fauna of El-Salam Canal was represented by only three phyla namely, Mollusca, Arthropoda and Annelida.This community structure is different from other parts of the River Nile. Only 14 species were recorded during the period of the study, while 17 species were reported in Rosetta Branch (Samaan et al., 1995) and 28 species in Helwan region (Abdel Gawad, 2001). This might be due to the shortly constructed canal with its water mass and the community is not yet established. However, the average biomass in the canal was much higher than that previously recorded in Rosetta Branch and Helwan region. This can be attributed to the large size and massive molluscan species especially at stations $\mathrm{N}$ and $\mathrm{V}$. The increasing number and size of Mollusca in the last two stations (situated at the end of the canal) may be attributed to the flushing of planktonic organisms which are the main food item for these grazing organisms. A similar observation was reported in the tidal Hudson River (Strayer et al.,1994). 
The seasonal variations of benthic community were especially reported for Chironomidae which showed their highest counts during spring, while their lowest average value was recorded during summer. This agrees with the observations of Fishar (1995) and Ramadan et al. (1998), who stated that increasing water temperature acclerates the development of larval stages (larvae leading to pupae and then to the adults).

The concentration of dissolved oxygen is one of the most important key factors in controlling aquatic life (Train,1979). From the results of Sabae and Abdel-Satar (2001), a positive corelation was recorded between average value of dissolved oxygen and different benthic groups ( 0.669 with Arthropoda and 0.670 with Mollusca and 0.668 with Annelida). This agrees with the results of Abdel Gawad (2001) in Helwan region.

Organic matter is usually used as an index of the amount of food available to benthic animals (Ballinger and Mckee,1971). Krzyzanek (1986) stated that great amounts of organic matter were rapidly brought into development of Oligochaeta. This disagrees with the present results at El-salam Canal, where a strong negative correlation $(-0.837)$ was observed between Oligochaeta and the organic matter, which means that there are other factors controlling the distribution of this group in the canal.

\section{REFERENCES}

Abdel Gawad, S. I. (2001). Studies on benthic invertebrates of Nile River at Helwan region. Ph. D. Thesis, Fac. Sci., ElMansoura Univ., 138 pp.

Ballinger, D. C. and G. D. Mckee (1971). Chemical characterization of bottom sediments. J. Water Poll. Contr. Fed., $4(2): 216$ pp.

Fishar, M. R. A. (1995). Studies on bottom fauna in Lake Nasser, Egypt. Ph. D. Thesis, Fac. Sci., Suez Canal Univ., 267 pp.

Ramadan, Sh. E.; Kheiralla, A. M. and Abd El-Salam, Kh. M. (1998). Benthic communities in the River, Nile Egypt. 1Aquatic stages of Insecta. Procedings of 8 th Intern. Conf. 
On : Environmental protection is a must, 5-7 May, 1998, Alexandria, Egypt, 178-189.

Sabae, S. Z. and Abdel-Satar, A. M. (2001). Chemical and bacteriological siudies on El-Salam Canal, Egypt. J. Egypt. Acad. Soc. Environ. Develop., 2(1): 173-197.

Samaan, A. A.; Abuol Ezz, S. M.; Salem, S. A., and Soliman, A. M., (1995). Benthic fauna of Rosetta Nile Branch (Egypt). Bull. Nat. Inst. Of Oceanogr. \& Fish., 21(1): 205-232.

Serag, M. S. and Kheder, A. A. (1996). The shoreline and aquatic vegetation of El-Salam Canal, Egypt. J. Environ. Sci., II:141-163

Strayer, D. L.; Hunter; C. H.; Smith, L. C. and C. K. Borg (1994). Distribution, abundance and roles of freshwater clams (Bivalvia , Unionidae) in freshwater tidal Hudson. Freshwater Biol., 31: 239-248.

Train, R. E. (1979). Quality criteria for water coastal hones publication lake waters. Int. Reuve. Ges. Hydrobiol., 50: 421-463.

Tumwesigye, C,; Yusul, S. K. and Makanga, B. (2000). Structure and composition of benthic macroinvertebrates of a tropical forest stream, River Nyamweru, Western Uganda. Afr. J. Ecol., 38:72-77. 


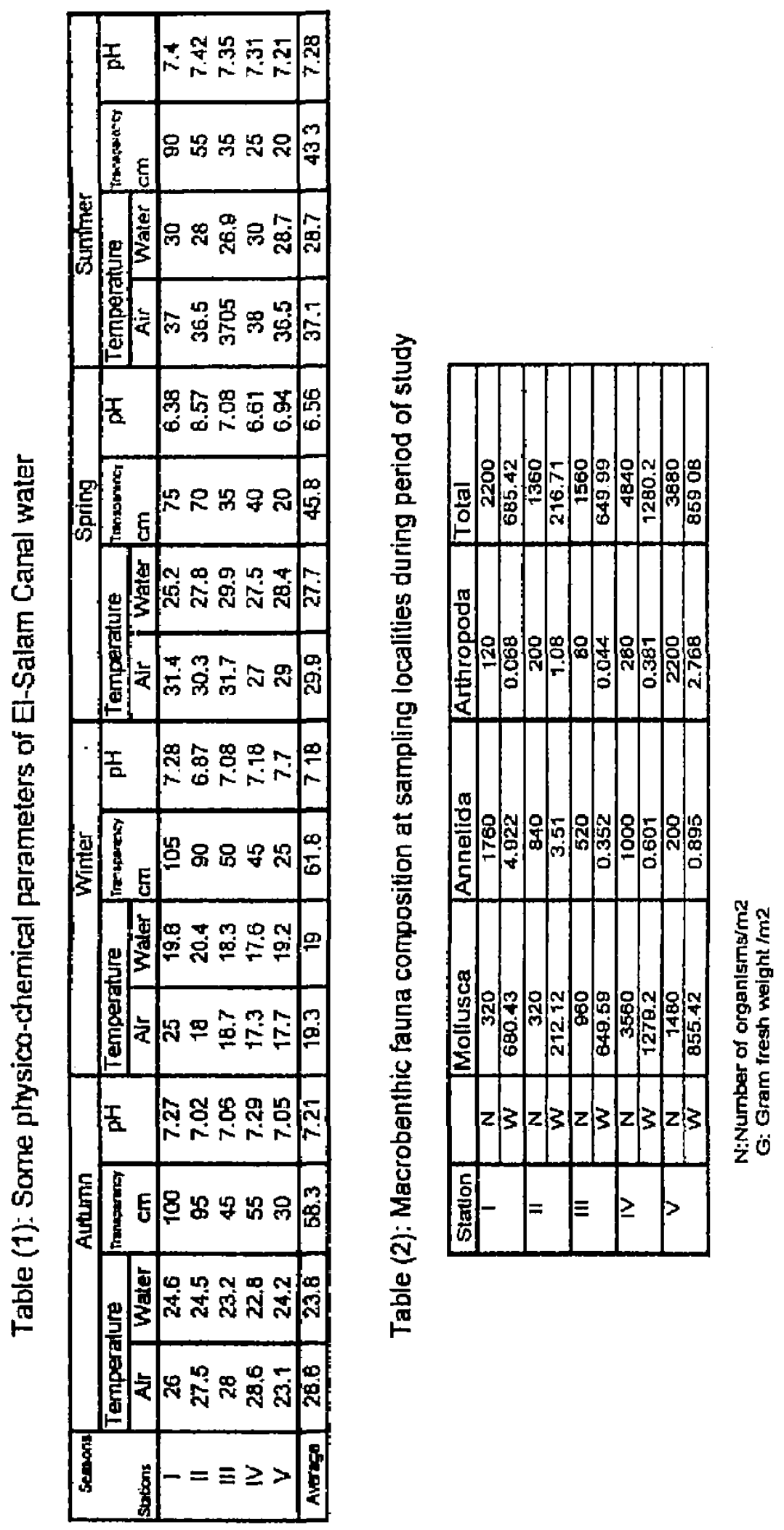




\section{STRUCTURE, COMPOSITION AND DISTRIBUTION OF BENTHIC MACROINVERTEBRATES IN EL-SALAM CANAL, EGYPT}

Fig (1).Comunnity composition of number and weight of total bottm fauna in El-Salam Canal

a) Number

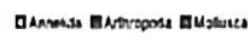

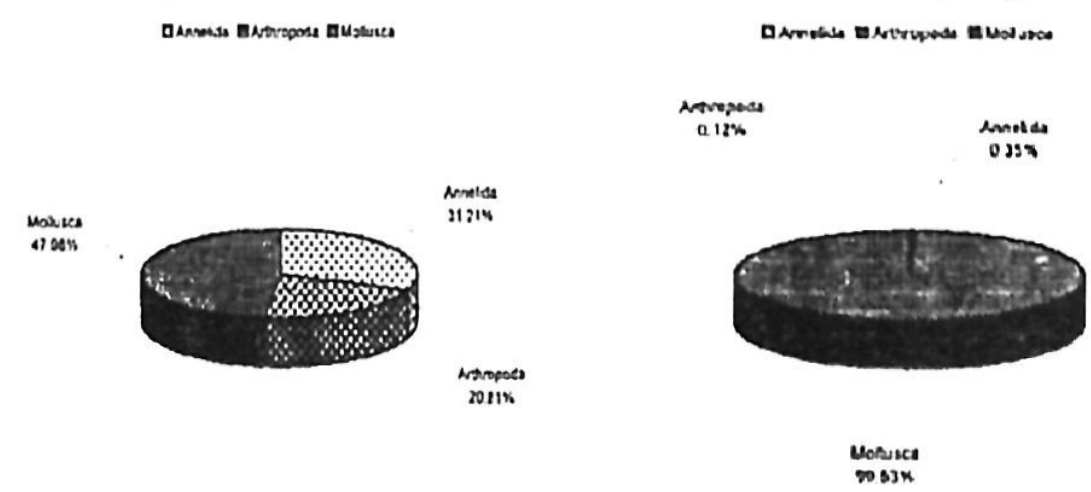

Fig (2). Distribution of number and weight of total bottom fauna in EI Salam Canal

a) Number

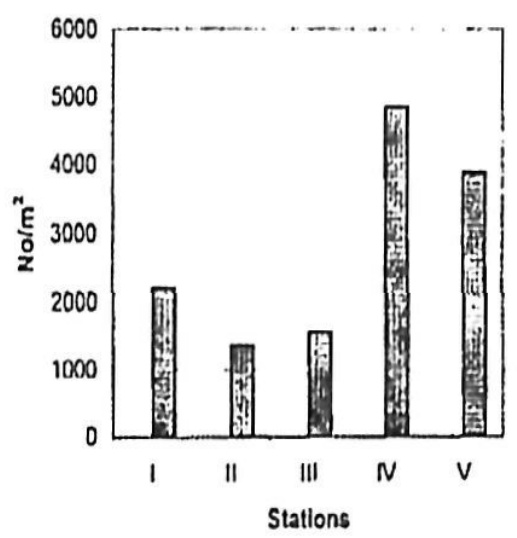

b) Weight

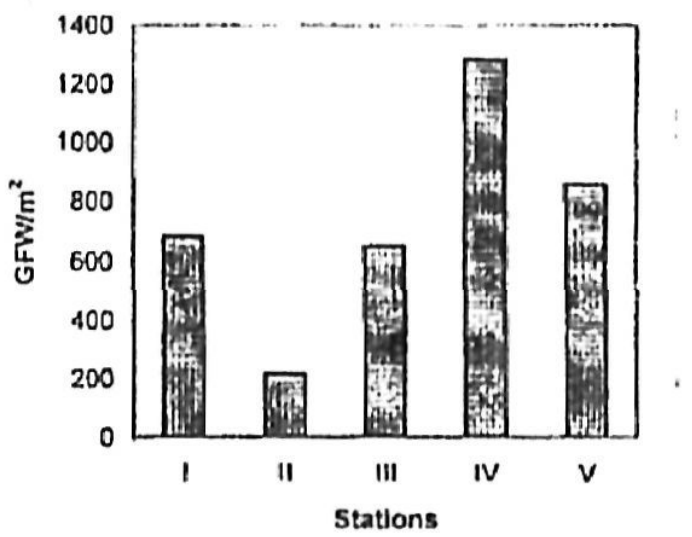

Fig (3). Seasonal variations of total macroinvertebrates during period of study

a) Number

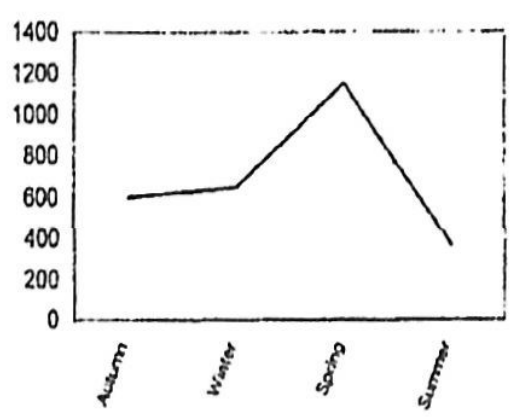

b) Weight

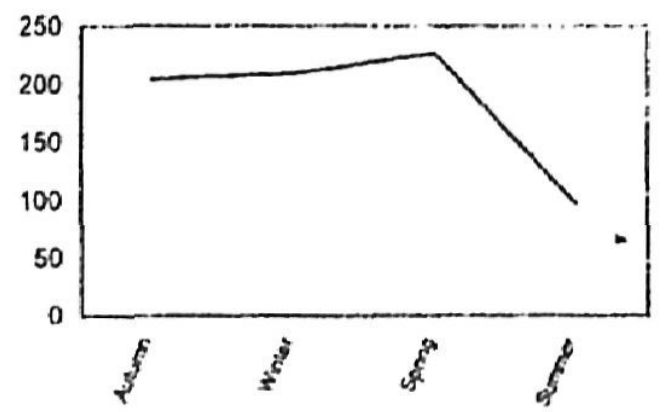


Fig (4).Distribution and seasonal variations of Mollusca in El Salam Canal

a) Number

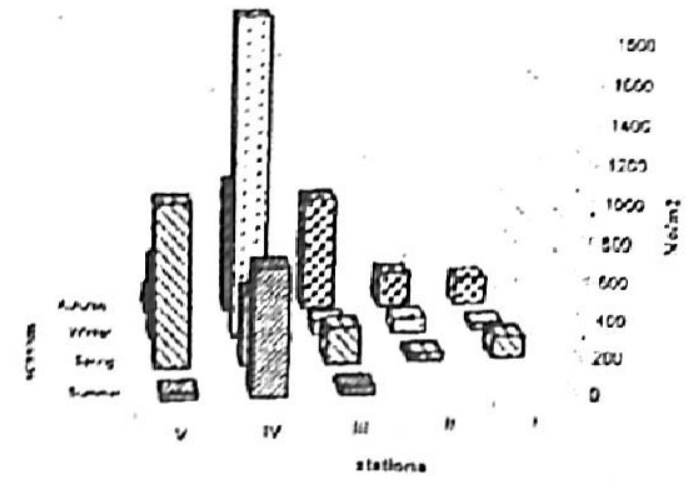

b) Weight

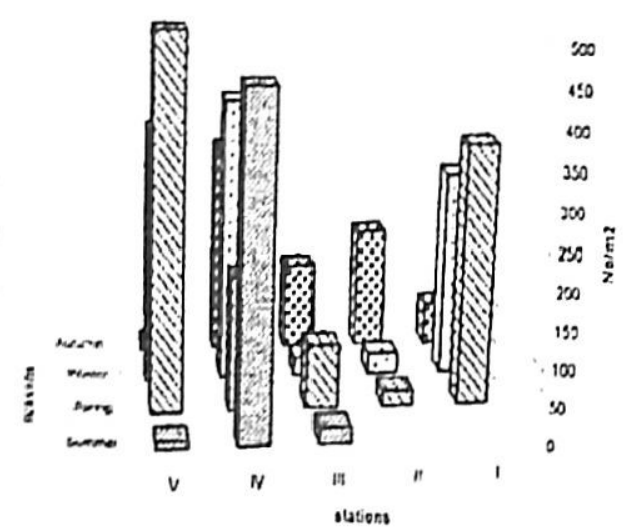
Fig ( 5 ).Distribution and scasonal variations of Annelida in El Salam Canal
a) Number b) Weight
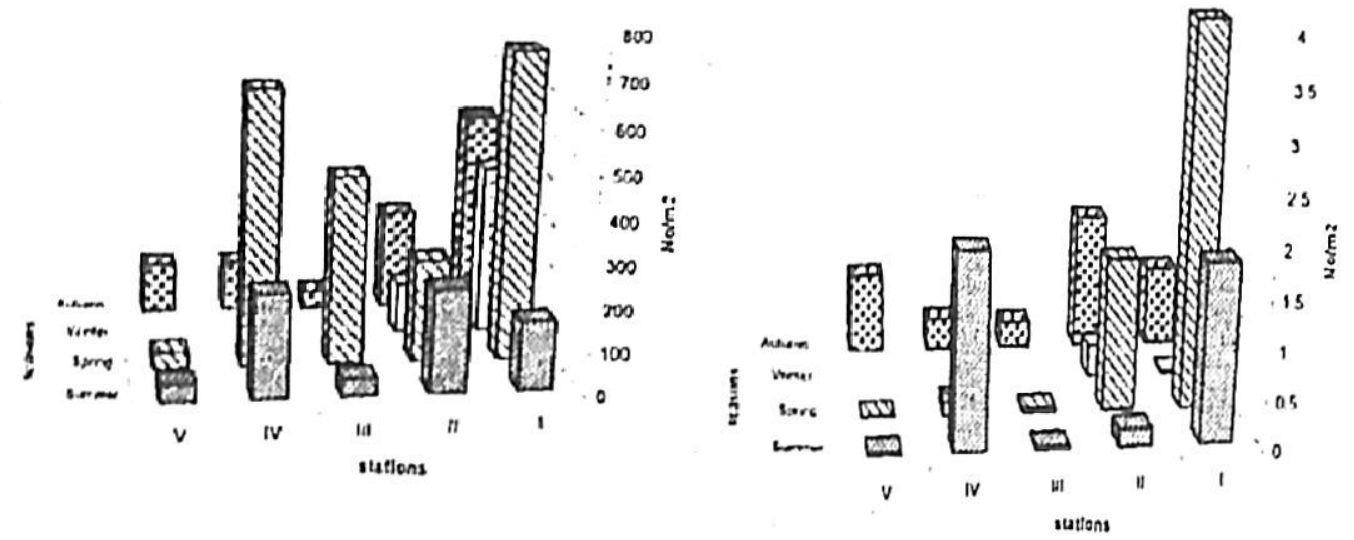

Fig ( 6 ).Distribution and seasonal variations of Arthropoda in El Salam Canal a) Number b) Weight
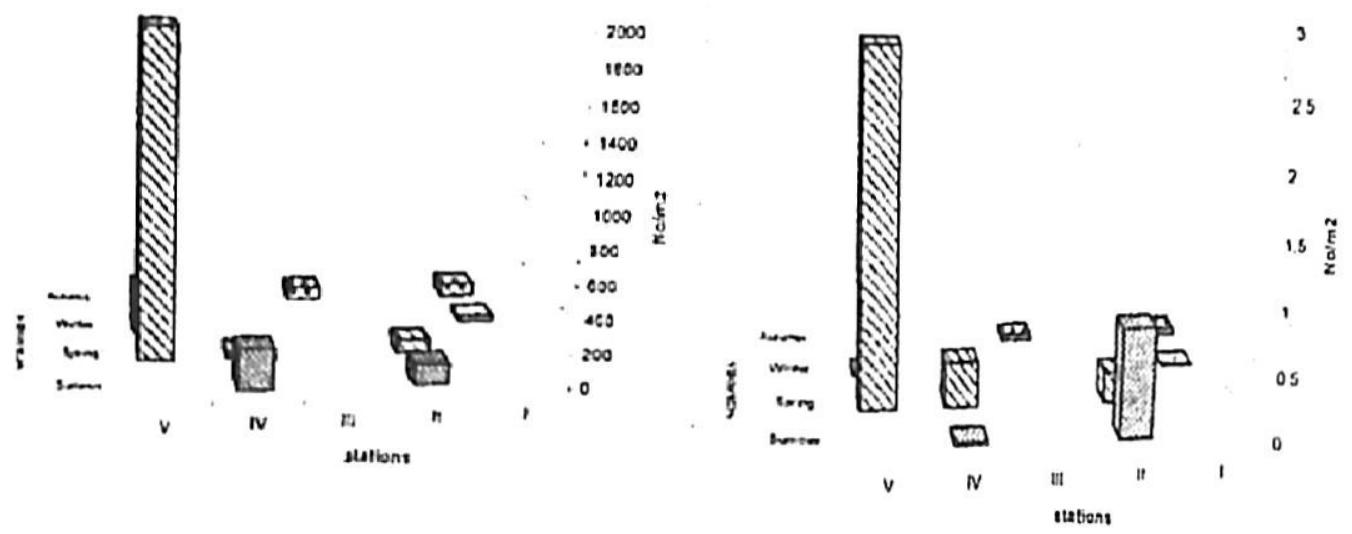